\title{
A puzzle regarding the Siberian Ectoedemia jacutica (Lepidoptera: Nepticulidae): re-examination and the first photographic documentation of the type series
}

\author{
Jonas R. Stonis ${ }^{1^{*}}$, \\ Asta Navickaite், \\ Arūnas Diškus \\ Faculty of Science and Technology, \\ Lithuanian University of Educational Sciences \\ and Baltic-American Biotaxonomy Institute, \\ Studentu St. 39, \\ LT-08106 Vilnius, Lithuania
}

\begin{abstract}
This article deals with Ectoedemia jacutica, a poorly known pygmy moth described by Puplesis from two specimens collected in Eastern Siberia, which later was synonymized with E. agrimoniae (Frey), and recently with E. spiraeae Gregor \& Povolnỳ. In the present paper, the type-series of E. jacutica is re-examined and, for the first time, illustrated with photographs of the adults and male genitalia. On the basis of comparison of E. jacutica with E. agrimoniae and E. spiraeae, it is assumed that E. jacutica represents a separate species.
\end{abstract}

Key words: Ectoedemia, Nepticulidae, Yakutia

\section{INTRODUCTION}

Pygmy moths (Nepticulidae) are generally global in distribution. The Siberian fauna of these tiny lepidopterans is very little studied: some six nepticulid species were recorded as occurring in Siberia (Sinev, 2008), only one, Ectoedemia jacutica, was originally described from this region (Puplesis, 1988).

The description of E. jacutica Puplesis, 1988 was based on two male specimens collected by A. Rastorguev in 1986 near Yakutsk City in Yakutia (or Yacutia, currently known as Sakha, the largest Republic of the Russian Federation). Unfortunately, all species published by R. Puplesis during 1984-1994, including E. jacutica, were described and illustrated from temporary slides in glycerol and by using poor quality microscopes, as well as

\footnotetext{
Corresponding author. E-mail: stonis@leu.lt
}

providing indian-ink drawings of genitalia which usually do not show all details of genital armature.

A few years later, in the monograph on the Eastern European and Asiatic Nepticulidae (Puplesis, 1994), E. jacutica was already listed as a junior synonym of Ectoedemia agrimoniae (Frey, 1858); the synonymy was provided without written explanation on the basis of the extended pseuduncus and shape of gnathos. The peculiar carinae of phallus, so characteristic for E. agrimoniae but absent in E. jacutica, were ingnored because of insufficient knowledge of the European E. agrimoniae. The same synonymy was erroneously followed in the Catalogue of the World Nepticuloidea \& Tischerioidea (by Diškus, Puplesis, 2003 in Puplesis, Diškus, 2003), and the Catalogue of the Lepidoptera of Russia (Sinev, 2008). Recently, in the Revision of Western Palaearctic Ectoedemia (van Nieukerken et al., 2010), E. jacutica was provided as a synonym of Ectoedemia spiraeae 
(Gregor, Povolny, 1983). According to the authors of the revision, this also fitted the distribution of E. spiraeae which, in the opinion of the authors, could be distributed in Japan and China (neither published nor confirmed yet), in contrast to E. agrimoniae, which is believed to occur only in Europe (van Nieukerken et al., 2010). In addition, the latter authors provided a sample of 5 male specimens collected in SW Altai, the genitalia of which looked very similar to E. spiraeae (or E. jacutica).

Having a task to help sort out the puzzle of E. jacutica, we made permanent mounts of the type specimens of E. jacutica in Euparal, re-examined and photographed genitalia slides of the holotype and paratype of E. jacutica, and studied external characters of the holotype.

\section{METHODS}

Methods for specimen dissection and description are outlined by Puplesis and Diškus (2003), and Diškus and Stonis (2012). After maceration of the abdomen in $10 \% \mathrm{KOH}$ and subsequent cleaning, male genital capsules were removed from the abdomen and mounted ventral side uppermost. The phallus was left in the genital armature. Abdominal pelts were stained with Chlorazol Black (Direct Black 38/Azo Black), and mounted in Euparal together with genitalia.

Permanent slides were photographed and studied using a Leica DM2500 microscope and Leica DFC420 digital camera. The descriptive terminology of morphological structures follows Puplesis and Robinson (2000), except for the term "aedeagus", which is refered here as "phallus".

\section{RE-DESCRIPTION OF ECTOEDEMIA JACUTICA}

Ectoedemia jacutica Puplesis, 1988: 26.

Diagnosis. Closely related to Ectoedemia spiraeae Gregor \& Povolnỳ, however, can be separated by the characters provided in the Table.

Male (Figs. 2-6). Forewing length: $2.5 \mathrm{~mm}$. Wingspan: $5.5 \mathrm{~mm}$. Head: palpi brownish cream or cream; frontal tuft yellowish orange; collar comprises piliform scales, yellowish orange;

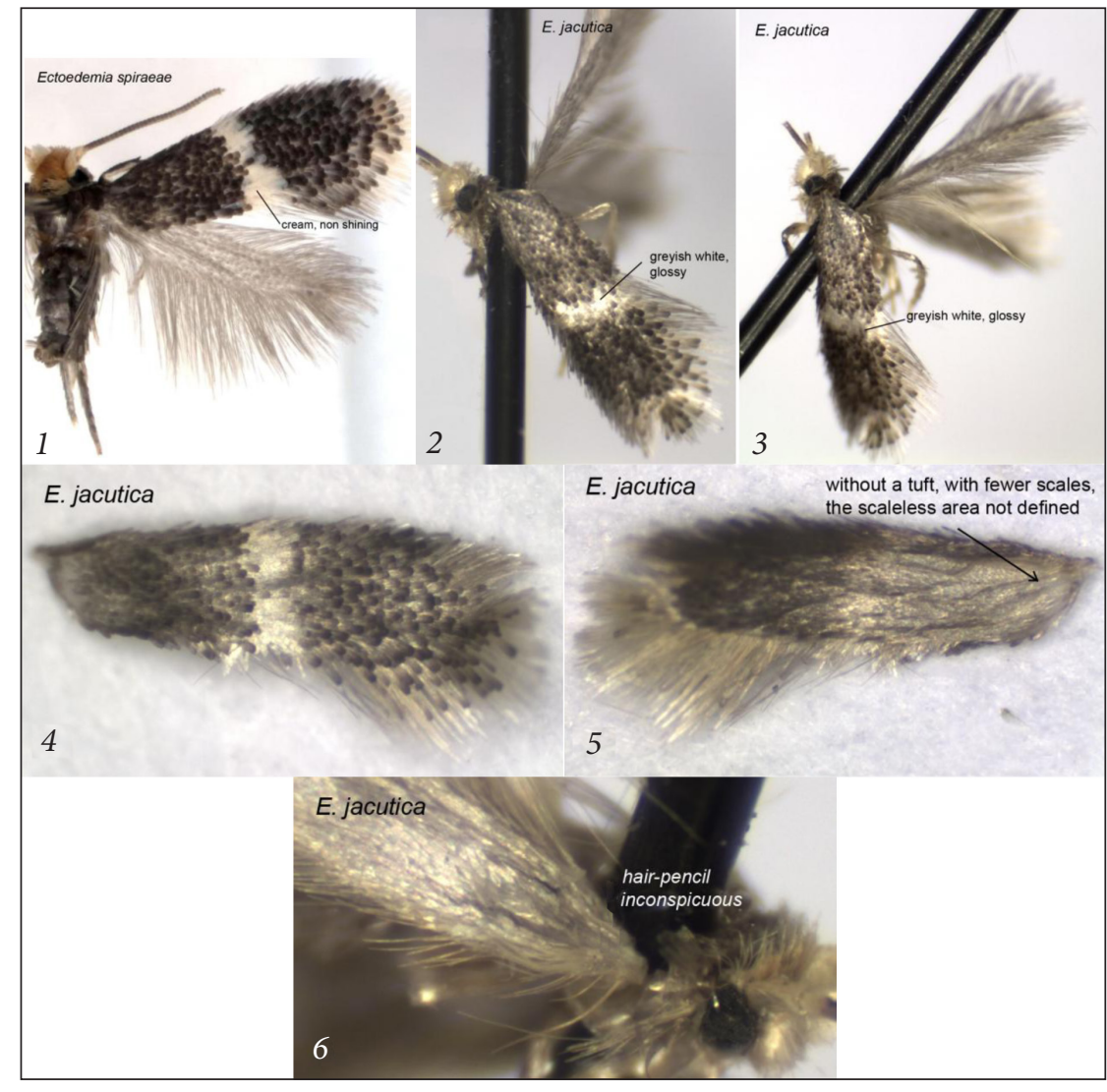

Figs. 1-6. Adults:

1 - Ectoedemia spiraeae, Romania, No. 4392 (courtesy of E. J. van Nieukerken, Naturalis Biodiversity Center, Leiden); 2, 6 - E. jacutica, holotype, Yakutsk, 05.07.1986, Zoological Institute of the Russian Academy of Sciences; 4 - forewing; 5 - same, underside; 6 - hindwing (basal part) 
eye-caps cream; the flagellum of antenna fuscous brown on the upper side, brownish cream on the underside, number of segments unknown (both flagelli broken in the only available paratype). Thorax and forewing irorated with fuscous brown and grey-brown scales. Fascia median, rather slender, slightly constricted in the middle, greyish white, slightly shining (at least glossy). Cilia brownish cream with a weakly defined dark cilia-line. The underside of forewing grey-brown, without a tuft near the costal retinaculum (Fig. 5); the base of forewing with fewer scales, but a scaleless area is not defined. Hindwing and its cilia brownish grey, with golden gloss at a certain angle of view; hindwing with brownish bristles along the costa (Figs. 6, 7) but without yellowish white hair-pencil.
Female. Unknown.

Male genitalia (Figs. 9-11). Capsule 275$325 \mu \mathrm{m}$ long. Pseuduncus distinctly extended, long. Gnathos with a wide but distally pointed tip (in holotype; Fig. 9); however, it could look truncate or with reduced caudal process if turned ventrally (paratype; Fig. 10); lateral arms long and slender. Valva 200-215 $\mu \mathrm{m}$ long; inner margin sligtly convex (bulging); tip pointed, inwards directed process. Transtilla with a very slender transverse bar and slender sublateral processes which approximately do not exceed $1 / 3$ of length of the valva. The ventral plate of vinculum short, with a distinct proximal excavation and lateral lobes (Fig. 11). Phallus 260-270 $\mu \mathrm{m}$ long, without carinae and cornuti, like a simple tube with granulated looking vesica (Fig. 10).

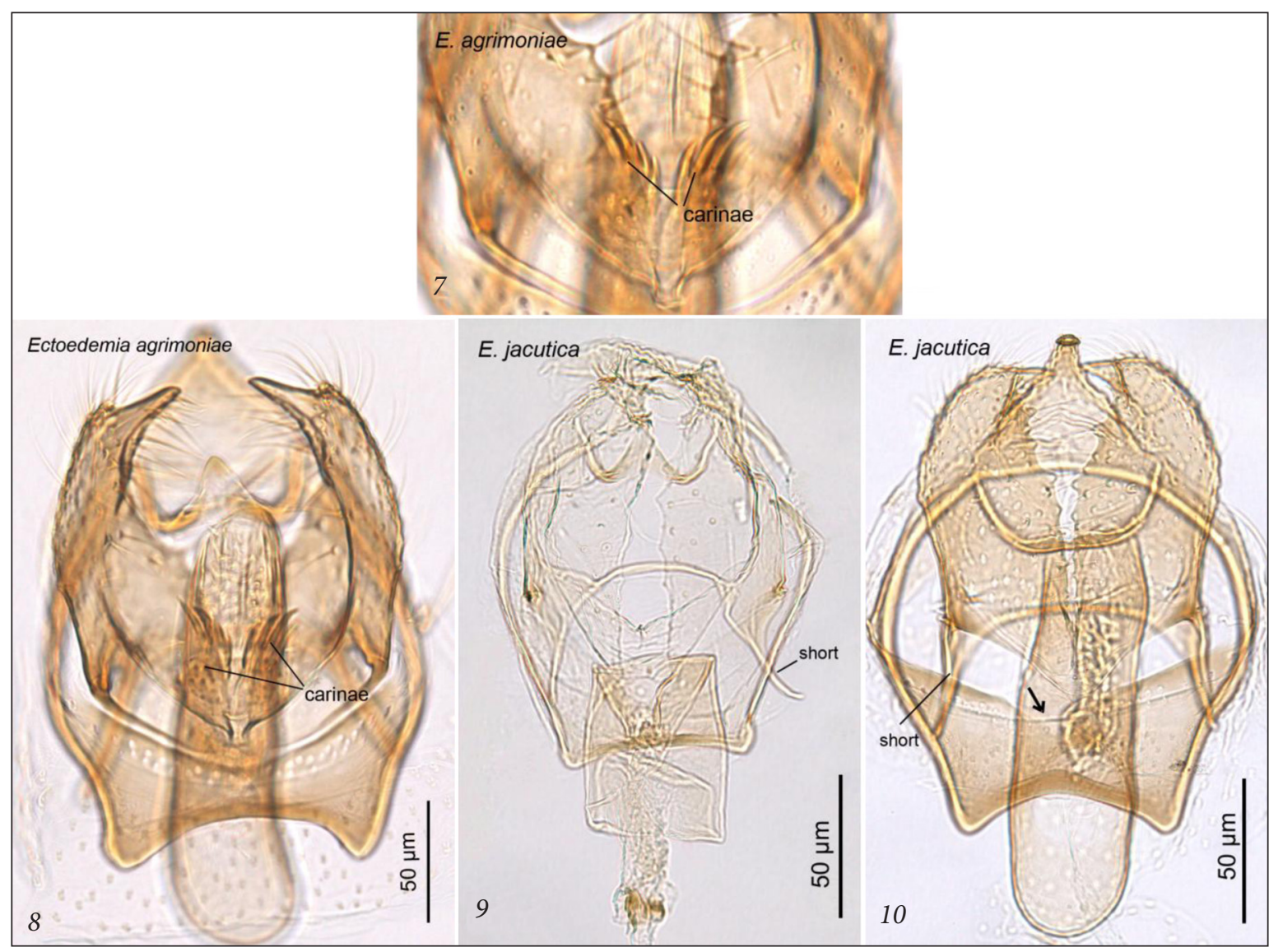

Figs. 7-10. Male genitalia: 7, 8 - Ectoedemia agrimoniae, Bulgaria, $11 \mathrm{~km} \mathrm{SW}$ Banya, elevation $370 \mathrm{~m}$, mining larva on Agrimonia eupatoria L., 24.07.2005, leg. A. Diškus, genitalia slide No. AN541 (Zoological Institute of the Russian Academy of Sciences); 9 - E. jacutica, holotype, Yakutsk, 05.07.1986, leg. A. Rastorguev, genitalia slide No. AN540; 10 - E. jacutica, paratype, same label, genitalia slide No. AN539 (Zoological Institute of the Russian Academy of Sciences) 


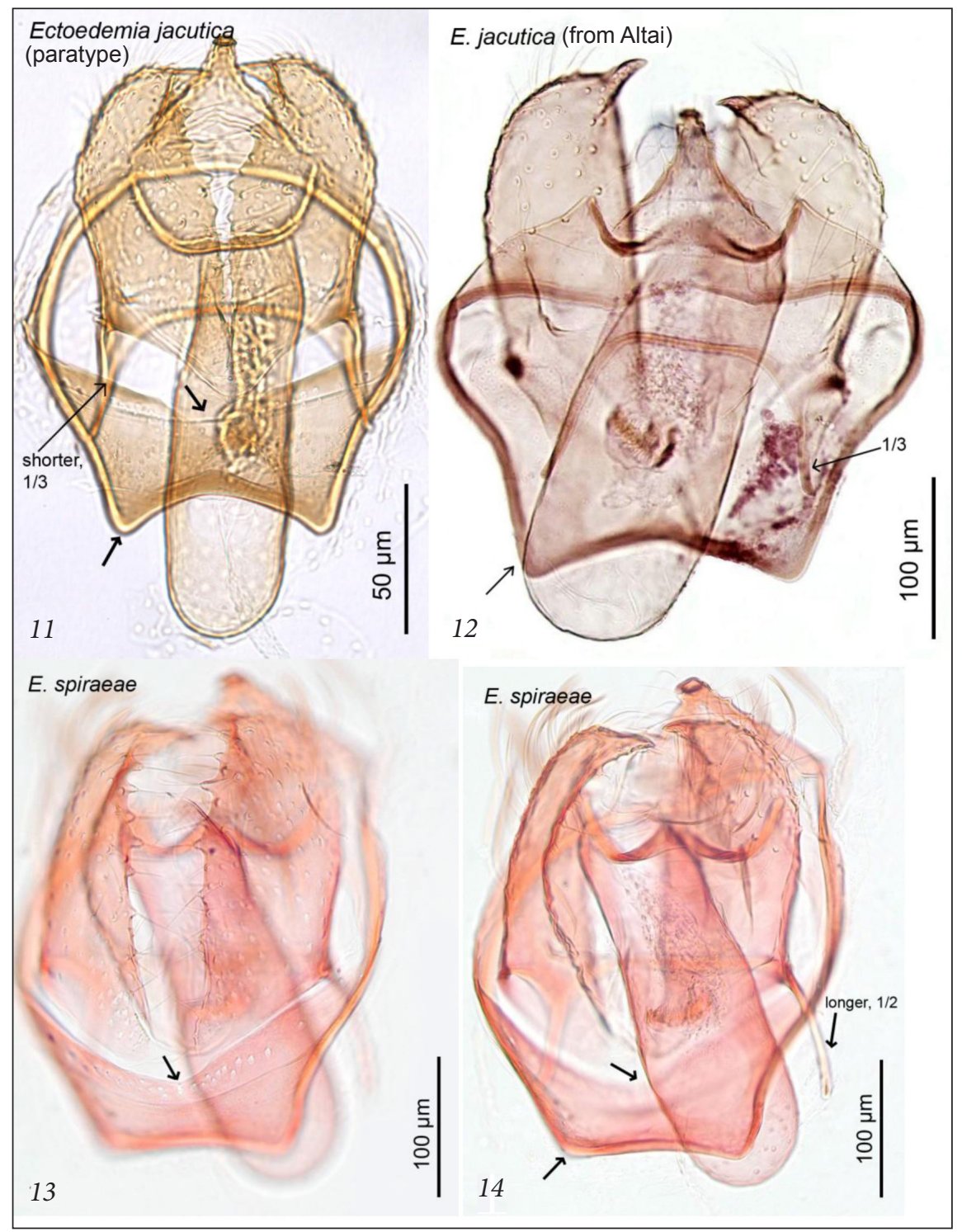

Figs. 11-14. Male genitalia: 11 - Ectoedemia jacutica, paratype, Yakutsk, 05.07.1986, A. Rastorguev, genitalia slide No. AN539; 12 - E. jacutica, W Altai, Katun valley, leg. Mikkola et al., genitalia slide No. 15041 JCK (courtesy of E. J. van Nieukerken, Naturalis Biodiversity Center, Leiden); 13, 14 - E. spiraeae, genitalia slide No. 4392 (EJvN), Romania (courtesy of E. J. van Nieukerken, Naturalis Biodiversity Center, Leiden)

Bionomics. Adults collected in early July.

Distribution (Fig. 15). The type-series came from Yakutsk (eastern Siberia) but similarly looking specimens are known from the Altai, southern Siberia (see discussions).

Material examined. Russia: $1 \hat{\delta}$ (holotype), Yakutia (now Rep. of Sakha), Yakutsk, 5 July 1986, A. Rastorguev, genitalia slide No. AN540; $1 \hat{\sigma}$ (paratype), same label data, genitalia slide
No. AN539 (Zoological Institute of the Russian Academy of Sciences).

Condition of the type-series. Adult of the holotype is pinned on a non-minutien pin (Figs. 2, 3), the right forewing broken up and placed in a pinned plastic container; genitalia slide in poor condition, some sclerites are weakly visible or damaged (Fig. 9). Adult of the paratype is missing, genitalia slide is in good condition (Fig. 10). 


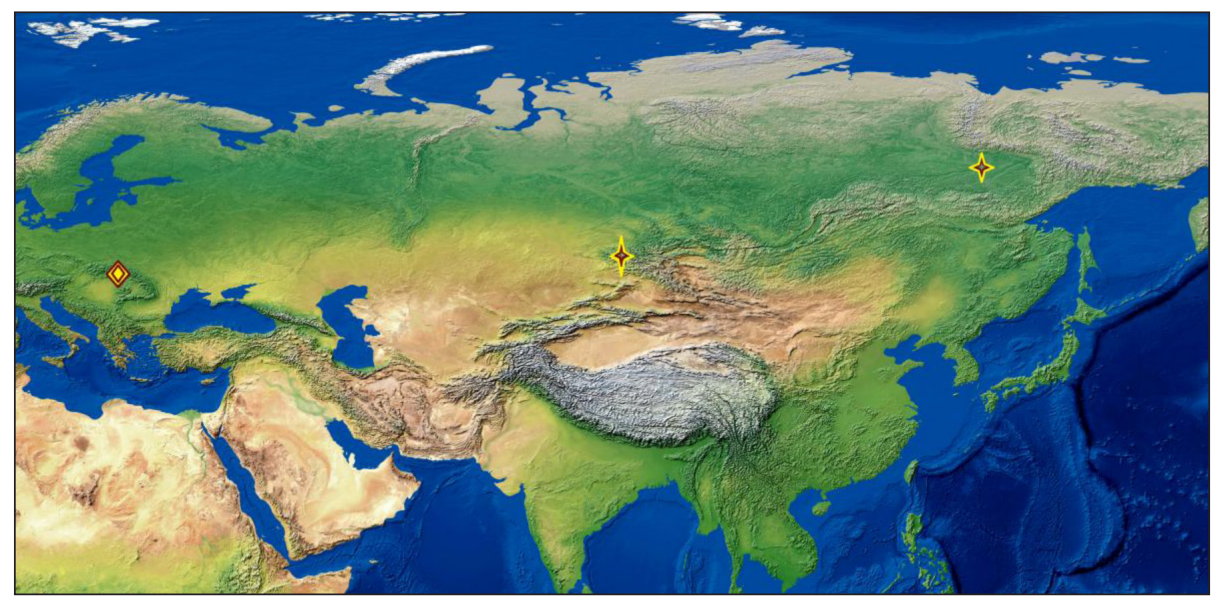

Fig. 15. Distribution of Ectoedemia jacutica (stars) and E. spiraeae (rhombus)

\section{DISCUSSION}

Without re-examination of the type-series of E. jacutica, it seemed impossible to understand whether the recent synonymy of E. jacutica with E. spiraeae was correct and whether E. jacutica and E. spiraeae actually represented two separate species. From the similar E. ag- rimoniae, E. jacutica clearly differs by its large divided carinae of phallus, caudally differently shaped valva and other characters. The separation of E. jacutica from the obviously closely related E. spiraeae seems rather difficult. Nevertheless, some characters which distinguish E. jacutica from E. spiraeae have been identified (Table).

Table. Comparison of Ectoedemia spiraeae and E. jacutica mostly based on the re-examination of the type series of E. jacutica

\begin{tabular}{|c|c|c|}
\hline Characters & E. spiraeae & E. jacutica \\
\hline $\begin{array}{c}\text { Fascia } \\
\text { of forewing }\end{array}$ & $\begin{array}{l}\text { Cream (non-metalic, non-shining) } \\
\text { (van Nieukerken, 1986) (Fig. 1). }\end{array}$ & $\begin{array}{l}\text { White, slighly shining (or glossy) } \\
\text { (Figs. 2-4). }\end{array}$ \\
\hline $\begin{array}{l}\text { Underside of } \\
\text { forewing }\end{array}$ & $\begin{array}{l}\text { With a tuft of white hair-scales arising } \\
\text { near the costal retinaculum and a large } \\
\text { scaleless area (van Nieukerken, 1986). }\end{array}$ & $\begin{array}{l}\text { Without a tuft near the costal retinacu- } \\
\text { lum (Fig. 5); base of the forewing with } \\
\text { fewer scales, a scaleless area not defined. }\end{array}$ \\
\hline Hindwing & $\begin{array}{l}\text { With a yellowish-white hair-pencil } \\
\text { (van Nieukerken, 1986). }\end{array}$ & $\begin{array}{l}\text { Hair-pencil inconspicuous. Brownish } \\
\text { bristles along the costa (Fig. 6). }\end{array}$ \\
\hline Capsule length & 266-287 $\mu \mathrm{m}$ (van Nieukerken, 1986). & $275-325 \mu \mathrm{m}$. \\
\hline Gnathos & $\begin{array}{c}\text { With a wide truncate tip } \\
\text { (according to van Nieukerken, 1986). }\end{array}$ & $\begin{array}{l}\text { With a wide but distally pointed tip } \\
\text { (Fig. 10); however, it also could be } \\
\text { inseparable from gnathos of E. spiraeae, } \\
\text { especially if turned ventrally (Fig. 11). }\end{array}$ \\
\hline $\begin{array}{l}\text { Sublateral pro- } \\
\text { cess of transtilla }\end{array}$ & Long, $1 / 2$ of length of the valva (Fig. 14). & $\begin{array}{l}\text { Shorter, } 1 / 3 \text { of length of the valva } \\
\text { (Fig. 11). }\end{array}$ \\
\hline $\begin{array}{c}\text { Ventral plate of } \\
\text { vinculum }\end{array}$ & $\begin{array}{l}\text { Without a proximal excavation } \\
\text { (a "usual" vinculum) (Fig. 13). }\end{array}$ & $\begin{array}{l}\text { With a specific proximal excavation } \\
\text { (Fig. 11). }\end{array}$ \\
\hline $\begin{array}{l}\text { Distal part of } \\
\text { vinculum }\end{array}$ & $\begin{array}{c}\text { Without lateral lobes } \\
\text { (or almost without lobes) (Figs. 13, 14). }\end{array}$ & $\begin{array}{c}\text { With broad triangular lobes or with } \\
\text { short lobes (Fig. 11). }\end{array}$ \\
\hline Distribution & $\begin{array}{l}\text { Europe (known from the restricted area } \\
\text { in Central Europe) (Fig. 15). }\end{array}$ & Asia (possibly widespread) (Fig. 15). \\
\hline Host-plant & $\begin{array}{l}\text { Spiraea media F. Schmidt } \\
\text { (Gregor, Povolnỳ, 1983). }\end{array}$ & $\begin{array}{l}\text { Unknown; other host-plant could be } \\
\text { expected (van Nieukerken, pers. comm.) }\end{array}$ \\
\hline
\end{tabular}


On the basis of these differences, we assume that E. jacutica and E. spiraeae represent two separate but closely related species. The specific proximal excavation of vinculum, among other characters, seems to be the most distinctive and easily observed feature of E. jacutica.

The examination of the photograph of male genitalia (Fig. 12) of the specimen collected in the Altai (by Mikkola et al.) but previously treated as E. spiraeae (van Nieukerken et al., 2010) showed that the series of 5 specimens from Southern Siberia could also belong to E. jacutica: proximally the ventral plate of vinculum with an excavation, distally vinculum with trianglar sublateral lobes and the sublateral process of transtilla are short.

As we have been dealing with tiny collection series, no host-plants and leaf-mines were known for the Asiatic specimens, and some mistery regarding the Siberian Ectoedemia jacutica still remains.

Received 30 October 2015 Accepted 17 November 2015

\section{References}

1. Diškus A, Puplesis R. Catalogue of the world Nepticuloidea \& Tischerioidea. In: Puplesis R, Diškus A, editors. The Nepticuloidea \& Tischerioidea (Lepidoptera) - a global review, with strategic regional revisions. Kaunas; 2003. p. 318-436.

2. Diškus A, Stonis JR. Leaf-mining insects of Lithuania. The Nepticulidae (Lepidoptera): taxonomy, chorological composition and trophic relationships [monograph]. Kaunas; 2012. Lithuanian.
3. Gregor F, Povolný D. Description of Ectoedemia spiraeae (Gregor \& Povolný, 1955) and designation of type specimens of Lithocolletis desertella Gregor \& Povolný, 1949. Časopis Moravského Musea v Brne; 1983; 68: 173-80.

4. Frey H. Nepticula agrimoniae. Entomologist's Wkly Intell. 1858; 4(84): 43-4.

5. Nieukerken EJ van. A provisional phylogenetic check-list of the western Palaearctic Nepticulidae, with data on hostplants (Lepidoptera). Entomol Scand. 1986; 17(1): 1-27.

6. Nieukerken EJ van, Laštuvka A, Laštuvka Z. Western Palaearctic Ectoedemia (Zimmermannia) Hering and Ectoedemia Busck s. str. (Lepidoptera, Nepticulidae): five new species and new data on distribution, hostplants and recognition. ZooKeys. 2010; 32: 1-82.

7. Puplesis R. Tri novykh dlya nauki vida neptikulid (Lepidoptera, Nepticulidae) iz aziatskoi chasti SSSR [Three new species of neptikulid moths (Lepidoptera, Nepticulidae) from the Asian part of USSR]. Lietuvos TSR aukštųjų mokyklų mokslo darbai, Biologija. 1988; 26: 24-9. Russian.

8. Puplesis R. The Nepticulidae of Eastern Europe and Asia: western, central and eastern parts. Leiden; 1994.

9. Puplesis R., Diškus A. The Nepticuloidea \& Tischerioidea (Lepidoptera) - a global review, with strategic regional revisions. Kaunas; 2003.

10. Puplesis R, Robinson GS. A review of the Central and South American Nepticulidae (Lepidoptera) with special reference to Belize. Bull Nat Hist Mus Entomol. 2000; 69(1): 3-114.

11. Sinev YuS. Catalogue of the Lepidoptera of Russia. Moscow; 2008. 
Jonas Rimantas Stonis, Asta Navickaitè, Arūnas Diškus

DÉL SIBIRINĖS Ectoedemia jacutica

(LEPIDOPTERA: NEPTICULIDAE) RŪŠIES

TAKSONOMINIO STATUSO: PAKARTOTINIS

RŪŠIES IŠTYRIMAS IR PIRMOJI TIPINĖS

SERIJOS DOKUMENTACIJA SKAITMENINĖS FOTOGRAFIJOS PRIEMONĖMIS

\section{Santrauka}

Straipsnyje nagrinëjamas iki šiol labai menkai žinomos mažujų gaubtagalvių rūšies Ectoedemia jacutica Puplesis taksonominis statusas. Ši rūšis buvo aprašyta remiantis dviem individais, rastais rytiniame Sibire. Vèliau rūšis buvo susieta su Europoje paplitusiomis E. agrimoniae (Frey) ir E. spiraeae Gregor \& Povolnỳ ir nebelaikoma savarankišku taksonu. Šiame straipsnyje buvo naujai ištirta E. jacutica tipinè serija ir atlikta pirmoji suaugèliu (imagų) bei patinų genitalinių struktūrų dokumentacija skaitmeninès fotografijos priemonemis. Toks E. jacutica, E. agrimoniae ir E. spiraeae morfologiniu struktūrų palyginimas leido pripažinti E. jacutica atskira, savarankiška rūšimi.

Raktažodžiai: Ectoedemia, Nepticulidae, Jakutija 